\title{
Agronomic Effectiveness of Phosphate Applied As Pyrophosphate for Corn in Calcareous Soils
}

\author{
N. M. Muhawish \\ Soil and Water Res. Dept., College of Agric. / Tikrit Univ., Iraq
}

\begin{abstract}
Two experiments were conducted to evaluate the agronomic effectiveness of pyrophosphate over five sources of phosphorus $(P)$ in calcareous soils. The pot experiment was carried out to grow corn on two calcareous soils (differed in texture), to compare $\mathrm{K}_{4} \mathrm{P}_{2} \mathrm{O}_{7}$ with $\mathrm{KH}_{2} \mathrm{PO}_{4}$ regarding their performance and effect on dry matter yield and $P$ concentration. $P$ was applied at five concentrations i.e. $0,10,20,50$, and $100 \mathrm{mg} \mathrm{Pkg}$ ${ }^{1}$. In the second experiment corn was grown in field on a calcareous clay soil. Equal amounts of $P\left(80 \mathrm{~kg} P \mathrm{ha}^{-1}\right)$ were applied to plots from all; $P$ sources used which consisted of control (zero P), M5 (2:1 ratio of PR: elemental $S)$, potassium pyrophosphate (PP), triple superphosphate (TSP), phosphate rock $(P R)$, and mono ammonium phosphate (MAP) and was applied at $80 \mathrm{~kg} P \mathrm{ha}^{-1}$. Results for the pot experiment showed that the performance of pyrophosphate was nearly the same as potassium dihydrogen phosphate in dry matter yield while the latter was significantly superior in P concentration. Internal efficiency (IE) for PP was higher than that for $\mathrm{KH}_{2} \mathrm{PO}_{4}$ in both soils. Results of the field trial showed that PP was next to MAP in corn straw, but it was next to M5 with no significant difference in corn ears, grain yield, and corn cobs with values reached 8175

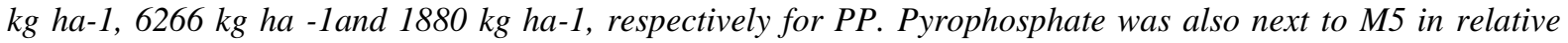
agronomic effectiveness (RAE) with values reached 164 and 170 for the two sources, respectively.
\end{abstract}

Keywords: agronomic effectiveness, calcareous soils, internal efficiency, PR, pyrophosphate.

\section{Introduction}

Orthophosphate $\left(\mathrm{H}_{3} \mathrm{PO}_{4}, \mathrm{H}_{2} \mathrm{PO}_{4}{ }^{-1}\right.$, and $\left.\mathrm{HPO}^{-2}\right)$ reactions with soil minerals have been studied by many researchers [1], [2]. Most reaction products, nature of reactions, and factors affecting it, were recognized. It was found that these reactions were rapid and the water soluble phosphate compounds, rapidly convert to relatively insoluble phosphate compounds in a matter of few hours of their application to soil [3], [4].These rapid reactions of phosphate fertilizer applied to soil minimize efficiency of phosphate fertilizers which are mainly calcium phosphate or ammonium orthophosphate, like Triple super phosphate (TSP) or Mono ammonium phosphate (MAP) [5]. For that reason, efficiency of TSP fertilizer is low in calcareous soils and does not exceed $30 \%$.Calcareous soils reduce the efficiency of $\mathrm{P}$ fertilizers due to rapid reactions between $\mathrm{P}$ applied and indigenous Ca present in soil [6], [7]. So, polyphosphate and pyrophosphate compounds were produced as alternatives for the common fertilizers or as additives for them in small ratios to reduce their adsorption and increase their efficiency [8]. The pyrophosphate anion has the structure $\mathrm{P}_{2} \mathrm{O}_{7}^{-4}$, and it is an acid anhydride of phosphate.<smiles>COP(=O)(O)OP(C)(=O)O</smiles>

It is unstable in aqueous solutions and slowly hydrolyzes into inorganic phosphates:

$\mathrm{P}_{2} \mathrm{O}_{7}^{-4}+\mathrm{H}_{2} \mathrm{O}$

$\mathrm{PPi}+\mathrm{H}_{2} \mathrm{O}------2 \mathrm{Pi}$

Potassium pyrophosphate $\left(\mathrm{K}_{4} \mathrm{P}_{2} \mathrm{O}_{7}\right)$ has a stable $\mathrm{pH}$ buffer capability which maintains long - term solution $\mathrm{pH}$ value. It is easy to dissolve in water, its solubility is $187 \mathrm{~g} / 100 \mathrm{ml}$ at $25^{\circ} \mathrm{C}$ [9].

Gilliam and Sample (1968) studied polyphosphate hydrolysis rates in soils with different chemical properties to assess the relative importance of chemical and biological influences. They found that coarse textured soil appeared to hydrolyze PP faster than fine - textured.Mcbeath et al. (2006) stated that there is preliminary evidence suggests that pyrophosphate may offer substantial benefits over traditional granular fertilizers in south Australian calcareous soils.Hydrolysis reactions of polyphosphate fertilizer in soil convert more condensed $\mathrm{P}$ species (two or more orthophosphate (OP) groups linked by oxygen bridges) to less condensed form of P [6], [12].Sutton and Larsen (1964) in their study on the use of pyrophosphate as a source for plant nutrition, stated that pyrophosphate hydrolysis in soil happens mainly by enzymes, for that, in soils with biological activity there is no difference between Ortho - $\mathrm{P}$ and Pyro -P for their ability to supply plant with $\mathrm{P}$, while if Pyro - $\mathrm{P}$ does not hydrolyze, then plant absorption of $\mathrm{P}$ will be less than the case of Ortho P.Gilliam (1970) concluded that Ortho and pyrophosphate were equally effective in supplying P to P- deficient wheat, corn, and barely, and that P- deficient roots absorbed the pyrophosphate ion per se and also rapidly 
hydrolyzed the PP.Regarding the mechanism of pyrophosphate effect on P availability, Raistrick (1949) suppose that pyrophosphate when absorbed on the surface of $\mathrm{CaCO} 3$ particle, may cause changes in surface structure of $\mathrm{CaCO} 3$ because of the suitable length of the chain $(\mathrm{P}-\mathrm{O}-\mathrm{P})$ of pyrophosphate which corresponds exactly with net system of the carbonate. While [16] see that pyrophosphate ions coat the active sites on the surface of calcium carbonate thus, reducing orthophosphate adsorption by carbonate.El-Zahaby and Chien (1982) found that $\mathrm{P}_{2} \mathrm{O}_{7}^{-4}$ ions cause an inhibition in formation of dicalcium phosphate (DCP) which is considered the first step in conventional fertilizer transformations to insoluble forms. Hashimoto et al.(1969) stated that the reason for that is that adsorption of pyrophosphate ions is faster compared with adsorption of ortho - $\mathrm{P}$ ions by calcareous soils systems.Torres - Dorante et al.(2006) stated that phosphorus fertilizer use efficiency (PFUE) was significantly higher for polyphosphate treatment in the silt loam soil and were related to a higher root length since no difference in the uptake per unit of root length among poly- $\mathrm{P}$ and ortho - $\mathrm{P}$ treatments were found.Amer et al. (1982) found that addition of sodium pyrophosphate (NaPP) to Monocalcium phosphate (MCP) at a pyro- $\mathrm{P} /$ ortho $-\mathrm{P}$ ratio of $1: 49$ or $5: 45$ markedly increased wheat grain yield on the desert soil (39\% CaCO3), and responses to $50 \mathrm{ppm} \mathrm{P}$ with additive were not statistically differentfrom those to $100 \mathrm{ppm} \mathrm{P}$ without additive. NaPP tended to increase P recovery from MCP by the wheat and by the following corn on the alluvial (4.1\% CaCO3) and only by the wheat on the desert soil. The results suggest that Diammonium phosphate (DAP) may not be recommended for soils high in $\mathrm{CaCO} 3$ content.A lot of experiments were conducted in acid and calcareous soils where TSP and pyrophosphate were used, and it was found that they are equivalent in supplying plants with $\mathrm{P}$ [13].It was also found, from hydrolysis study and $\mathrm{P}$ uptake from pyrophosphate compounds labelled with $\mathrm{P}-32$ that the dissolution was exponential and that the dissolution time was in the range 4-100 days for different soils [20].Amer et al. (1982) found when they apply pyrophosphate at a ratio of $2 \%$ and $5 \%$ of the $\mathrm{P}$ fertilizer applied that pyrophosphate led to a significant increase in dry matter yield and total P uptake in the cultivated crop.Zapata and Roy (2004) mentioned that the most important index used to express the agronomic performance of phosphate rock (PR) relative to water soluble $\mathrm{P}$ fertilizers is called the relative agronomic effectiveness (RAE) of a given P test fertilizer [22]. This index can be calculated by expressing as a percentage the ratio of the response of the test fertilizer( treatment - control) to the response of the standard fertilizers when both are applied at the same rate :

$$
\mathrm{RAE}=[(\mathrm{Yf}-\mathrm{Yc}) /(\mathrm{Yr}-\mathrm{Yc})] * 100
$$

Where:

Yf = average yield or uptake obtained by the tested fertilizers

$\mathrm{Yr}=$ average yield or uptake obtained by the reference fertilizer (TSP)

$\mathrm{Yc}=$ average yield or uptake obtained in treatments without $\mathrm{P}$ additives

The objective of this study was to evaluate the effectiveness of Pyrophosphate over other sources of $\mathrm{P}$ in calcareous soils.

\section{Materials And Methods:}

The study consisted of two experiments; the first was a pot experiment while the second was a field experiment.

\section{Pot experiment:}

A pot experiment was conducted to grow corn (Zea mays varRabee) as a test crop in the green house of Soil and Water Resources Center / Ministry of Science and Technology. This experiment aimed at comparing tetra potassium phosphate $\left(\mathrm{K}_{4} \mathrm{P}_{2} \mathrm{O}_{7}\right)$ with dihydrogen potassium phosphate $\left(\mathrm{KH}_{2} \mathrm{PO}_{4}\right)$ and assessing their superiority and effect on dry matter yield and phosphorus concentration in plant, and also to assess the optimum rate of application for the second experiment (field).

Table 1 shows some characteristics of the two soils used in this experiment, where it is shown that the first soil is a heavy textured soil while the second soil is a medium textured soil. Analyses were conducted according to the standard methods mentioned by [23]. Soils were taken from the depth $0-30 \mathrm{~cm}$, dried, ground to pass through $2 \mathrm{~mm}$ sieve. Three kilograms of soil were packed in each pot and were cropped to corn. Nitrogen $(\mathrm{N})$ was applied at a rate of $320 \mathrm{~kg} \mathrm{~N}$ ha-1 as urea divided on two doses, the first was at planting and the second was applied after plant reached $20 \mathrm{~cm}$ tall. Phosphorus (P) was applied at five concentrations i.e., 0 , $10,20,50$, and $100 \mathrm{mg} \mathrm{P} \mathrm{kg-1} \mathrm{soil} \mathrm{as} \mathrm{potassium} \mathrm{pyrophosphate} \mathrm{and} \mathrm{dihydrogen} \mathrm{potassium} \mathrm{phosphate.} \mathrm{This} \mathrm{part}$ of the study consisted of three factors:

1. Type of fertilizer

2. Phosphorus level

3. Soil type 
Pots were arranged in a randomized complete block design (RCBD) in three replicates. The experiment lasted for ten weeks after planting. Corn dry weight was measured and $\mathrm{P}$ concentration was determined after harvest. Internal Efficiency [IE],[24] was also determined according to the following equation:

$$
\text { IE = yield of dried tops / P uptake }
$$

\section{Field Experiment:}

The field experiment was conducted on a clay soil at the experimental station of the soil and Water Resources Research Center. Table 2 shows some characteristics of the field soil before planting, where it is shown that the electrical conductivity (EC) of soil is $3.6 \mathrm{dS} . \mathrm{m}^{-1}$ and the $\mathrm{pH}$ is neutral tend to slightly alkaline, available phosphorus (P) (extracted with $0.5 \mathrm{M}$ of NaHCO3) is $8.85 \mathrm{mg} \mathrm{P} \mathrm{kg}^{-1}$ soil. The table also shows that the texture of the soil is clay. The soil classified as sedimentary soil (TypicTorrifluvent). The field was prepared through tillage, crushing and levelling. Experimental units were prepared at field in $4 * 4 \mathrm{~m}$ plots. Equal amounts of phosphorus were applied to plots from all the P sources used. The sources consisted of control (without P), M5 [which is the same formula used by Muhawish and Razaq (2009) and was formulated by mixing $2: 1$ ratio of phosphate rock : elemental Sulphur of which $20 \%$ of S added was $\mathrm{H}_{2} \mathrm{SO}_{4}$ ], potassium pyrophosphate (PP), triplesuperphosphate(TSP), phosphate ROCK (PR), and mono ammonium phosphate (MAP). Table 3 shows some characteristics of the PR used in the study.

These sources were applied to give $40 \mathrm{mg} \mathrm{P} \mathrm{kg}^{-1}$ soil which represents nearly $80 \mathrm{~kg} \mathrm{P}^{-1}$ which is the rate recommended for corn in such soil. Nitrogen was applied as urea $(46 \% \mathrm{~N})$ to all experimental units at a rate $322 \mathrm{~kg} \mathrm{Nha}^{-1}$, divided into two doses, the first $\left(138 \mathrm{~kg} \mathrm{Nha}^{-1}\right)$ was applied at planting and the second $(184 \mathrm{~kg} \mathrm{~N}$ $\mathrm{ha}^{-1}$ ) was applied when plants reached $20 \mathrm{~cm}$ high. The phosphate sources were mixed with the first dose of urea and incorporated with surface soil upon land preparation, while the second dose of urea was broadcasted. Corn seeds (variety Rabee) were grown in July 2013 on rows; $75 \mathrm{~cm}$ between rows, $25 \mathrm{~cm}$ was left between plants. The experiment consisted of six treatments, each with four replicates in a randomized complete block design (RCBD). Data were subjected to (one -way ANOVA, and significant differences in means between the treatments were compared by the (Fisher's protected least significant difference LSD) procedure at $\mathrm{p}<0.05$ with the SPSS 17.0 software program [26]. Crop service operations were done as required. Furrow irrigation was practiced according to plant needs. After harvest in Nov. 2013 some plant parameters were studied. Corn straw, corn ears weight, grain yield, and corn cobs weight, were measured for each treatment. Relative agronomic effectiveness (RAE) was calculated according to the following equation:

$$
\mathrm{RAE}=\left[\left(\mathrm{Y}_{\mathrm{F}}-\mathrm{Y}_{\mathrm{C}}\right) /\left(\mathrm{Y}_{\mathrm{R}}-\mathrm{Y}_{\mathrm{C}}\right)\right]^{*} 100 \quad(\text { Engelstad et al., 1974) }
$$

\section{Pot experiment}

\section{Results And Discussion:}

Table 1 shows characteristics of the two soils used in this study. The first soil is heavy textured (clay) and the second is medium textured (loam), with suitable salinity level to grow corn within conditions of dry regions like Iraq where the salinity level is high in most soils because of no exposure to suitable level of leaching due to rain lack and the dependenceof cultivation mainly on irrigation, and the high rate of evaporation all over the season (at summer) which characterized by a highly temperatures. The phosphorus content of the two soils is low and below critical level which will facilitate the (process of) comparison between fertilizers.

Dry matter yield of corn which gives the appropriate function of $\mathrm{P}$ fertilizer effectiveness applied to the two soils is given in Table 4 , where it is shown that dry matter yield for the two treatments, potassium pyrophosphate $\left(\mathrm{K}_{4} \mathrm{P}_{2} \mathrm{O}_{7}\right)$ and potassium dihydrogen phosphate $\left(\mathrm{KH}_{2} \mathrm{PO}_{4}\right)$, is increasing by the increase in $\mathrm{P}$ level added to the two soils. The higher yield of dry matter in both soils and both fertilizers was at the higher level of $\mathrm{P}$ added (32.31 and $32.71 \mathrm{~g}$. pot $^{-1}$ ) for the two fertilizers, respectively. When comparing the two fertilizers it is

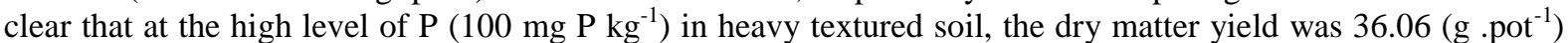
for the pyrophosphate while it was 34.49 (g. pot-1) for potassium dihydrogen phosphate. At the level 20 ( $\mathrm{mg} \mathrm{kg}^{-}$

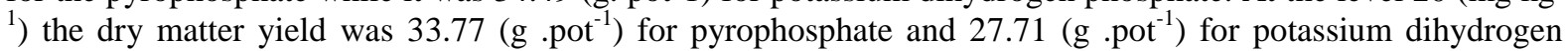
phosphate which means that pyrophosphate was accounted for $22 \%$ increase in dry matter yield higher than potassium dihydrogen phosphate which is in accord with [27], [19]. This result confirm the fact that the effectiveness of pyrophosphate is larger than potassium dihydrogen in soils like this one, which may be due to the nature of this fertilizer which is less fast reacted with soil components from the traditional orthophosphate fertilizers which is in accord with [28], [29]. Heavy textured soil was significantly superior over medium textured soil with values reached 30.70 and 26.52 (g .pot-1), respectively which is in accord with results of[30] and [31].The overall effect of the $P$ source was not significant, although it was higher for the pyrophosphate treatment which is in accord with [27]. The dry matter yield of corn for both soils and both fertilizers also influenced by the level of applied $\mathrm{P}$, it was increased by application of the higher level of $\mathrm{P}$ [32].The highest dry matter yield achieved was at the pyrophosphate treatment at the P level $100(\mathrm{mg}$ Pkg-1) and on the heavy 
textured soil. While in medium textured soil the potassium dihydrogen phosphate fertilizer was more efficient than pyrophosphate which may be due to the difference in phosphorus reaction speed in soil which depends on soil components since the $\mathrm{P}$ reaction speed in heavy textured soil is larger than light or medium textured soils[33].

Table 5 reported that $\mathrm{KH}_{2} \mathrm{PO}_{4}$ elicit a significant increase in $\mathrm{P}$ concentration over $\mathrm{K}_{4} \mathrm{P}_{2} \mathrm{O}_{7}$ with values reached 1678 and 1495 (mg P kg${ }^{-1}$ plant tissue), for the two sources, respectively, which is in accord with [27]. Results also showed that $\mathrm{P}$ concentration in plant tissues grown in medium textured soil was higher than that for the heavy textured soil for the two fertilizers with values reached 1720 and $1412\left(\mathrm{mg} \mathrm{P} \mathrm{kg}^{-1}\right.$ plant tissue) for the two soils, respectively which may be due to the fact that the dry matter in heavy textured soil was higher than medium textured soil, which clarify the effect of biological dilution in this case [34],[35]. It is also shown that in both soils, the $\mathrm{P}$ concentration in plant tissue is increasing by the increase in $\mathrm{P}$ applied to soil [36], [37].The highest $\mathrm{P}$ concentration achieved $2206\left(\mathrm{mg} \mathrm{P} \mathrm{kg}^{-1}\right.$ plant tissue) was at the treatment $\mathrm{KH}_{2} \mathrm{PO}_{4}$, in medium textured soil The relationship between yield of dried tops and $\mathrm{P}$ concentration measured in the tops which is called the internal efficiency IE [24] was different for the two sources of P used in this study (Table 6). This indicates that the plants have different internal efficiency of $\mathrm{P}$ use curves for the two sources of $\mathrm{P}$ fertilizers. That is once the $\mathrm{P}$ has been taken by the plants, the same $\mathrm{P}$ concentration or $\mathrm{P}$ content in the plant tops were generally related to different yields when $P$ was derived from different fertilizers [38]. The mean value for all the P levels indicate that pyrophosphate was superior for the highest IE values, 767 and 605 for the heavy and medium textured soil, respectively, while the values for $\mathrm{KH}_{2} \mathrm{PO}_{4}$ were 695 and 546 for the two soils, respectively. Results in table 5 also showed that the IE decreases with increase in P level.

\section{Field experiment:}

The properties of the field soil are presented in table 2 . Where it is shown that the soil is heavy textured (silty clay loam) and the $\mathrm{P}$ level as an average for all experimental units is larger than the critical level of $\mathrm{P}$ which may affect the results of this experiment. The effect of fertilizer treatments on corn strawyield and corn ears weight of corn is illustrated in table 7. The application of MAP achieved the highest significant value of corn straw but the difference was not significant with pyrophosphate which is in accord with results of [30] about the effectiveness of pyrophosphate as a P source in two calcareous soils differed in texture. It is also shown that the treatment which was not given $P$ achieved a good yield of corn straw $\left(5500 \mathrm{~kg} \mathrm{ha}^{-1}\right)$, this may assure the previous conclusion about the native available $\mathrm{P}$ in soil originally, though its corn straw yield was less than any treatment received phosphorus and even lower than phosphate rock $\left(8000 \mathrm{~kg} \mathrm{ha}^{-1}\right)$. Results showed that MAP was the most efficient fertilizer regarding their effectiveness in increasing corn straw. The increase was higher by $113 \%$ than the control and higher by $18 \%$ than TSP. The superiority of MAP for this growth parameter may be due to its content of nitrogen which may enhance the vegetative growth of corn, which is in agreement with [30] but not in agreement with [8]. Regarding pyrophosphate the increase in corn straw at this treatment was higher by $89 \%$ than that of the control and at a percentage of $5 \%$ increase over TSP. This may assure clearly the effectiveness of pyrophosphate compounds in soil [27]. The new fertilizer formula (M5) was more effective than TSP but the differences between them were not significant. M5 was also less effective in increasing corn straw than MAP. Results in table 7 also show that M5 achieved the highest corn ears weight which is in agreement with the results of [25] but it did not differ with pyrophosphate. The least value of corn ears weight was at the control treatment $(5625 \mathrm{~kg}$ ha-1).The increase in corn ears weight for M5 and pyrophosphate over TSP were $12 \%$ and $11 \%$, respectively.

Table 8 report the effectof fertilizer treatments on grain yield and corn cobs weight (kg ha-1). M5 acquired the highest value over other sources of P regarding grain yield of corn with value reached 6323 (kg ha1) but it did not differ significantly with pyrophosphateand MAP which gave 6266 and 6107 (kg ha-1), respectively.This result is in accord with results of [25] who found that M5 source of P was superior over other $\mathrm{P}$ sources used in their study.The same trend of values was noticed for corn cobs for the performance ofP sources in this study. M5 was superior with values reached 1892 (kg ha-1) followed by pyrophosphate with no significant difference between them. Mono ammonium phosphate (MAP), TSP, and PR gave the following values for corn cobs; 1696, 1691, and 1581 (kg ha-1). The control treatment gave the lowest value of corn cobs 1294 (kg ha-1). Relative Agronomic Effectiveness results are presented in table 9. Using TSP as the standard $(100 \%)$ and on the basis of corn grain yield, RAE (equ.1) of the PR was 57, while RAE of MAP was 147 which was less than M5 and pyrophosphate. M5 as a P source has a RAE of 170 which is higher than PR (57) which may be due to the industrial process of this source which combines both the partially acidulation by $\mathrm{H}_{2} \mathrm{SO}_{4}$ which works initially to supply P, and Sulphur content which works later by eliciting acid formation to enhance P availability [39]. Pyrophosphate was next to M5 in its RAE (164). The highest RAE happens with M5 which was 170, so the five sources of $\mathrm{P}$ followed the order M5>pyrophosphate>MAP>TSP> PR. This is in agreement with [40] work who reported that PR with high solubility is nearly as effective or superior as the TSP standard. 


\section{Conclusion}

The present study affirms the possibility of using pyrophosphate as a $\mathrm{P}$ source for corn in calcareous soils of Iraq. The performance of pyrophosphate was not differed significantly with M5 (the acidulated decalcinated PR of Iraqi source) which was very successful in field trials with their effect on yield and yield components of corn, and their high relative agronomic effectiveness compared with other conventional $\mathrm{P}$ sources, but the results need more feasibility studies to support the current results.

\section{References}

[1] Yi S.R.Chen, J. N. Butler; and W. Stumm, Kinetic study of phosphate reactions with aluminum oxide and kaolinite. Environ. Sci. Technol. 7(4), 1973, 327- 332.

[2] J. A.Kittrick, and M. L. Jackson, Rate of phosphate reaction with soil minerals and electron microscope observations on the reaction mechanism,Soil Sci. Soc. Am. Proc. 19, 1955,292 - 295.

[3] J. F.Haseman, E. H. Brown, and C. D. Whitt, Some reactions of phosphate with clays and hydrous oxides of iron and aluminum.Soil Sci. 70, 1950, $257-271$.

[4] W. L.Lindsay, A. W. Frazier, and H. F. Stephenson, Identification of reaction products from phosphate fertilization in soils. Soil Sci. Soc. Am. Proc. 26, 1962, 446- 452.

[5] S. Larsen, Soil phosphorus. Adv. Agron. 19, 1967, 151- 210

[6] W. L.Lindsay, 1979. Phosphates.P. 162- 205.In W. L. Lindsay (ed.) Chemical equilibria in soils (John Wiley and Sons, New York, 1979).

[7] M. J.Hedley, and M. J. Maclauglin, Reactions of phosphate fertilizers and by- products in soils. In J. T. Sims and A. N. Sharpley (ed.) Phosphorus: Agriculture and the environment, (Agron. Monogr.No. 46.ASA, CSSA< and SSSA. Madison, WI. 2005)P. 181 252.

[8] F.Amer., M. Khalil, and G. S. Diab, Agronomic effectiveness of pyrophosphate as additive to mono calcium phosphate and di calcium phosphate in calcareous soils. Soil Sci. Soc. Am. J. 46, 1982, 579- 583.

[9] J. R. Van Wazer, E. J. Griffith, and J. F. McCullough, Structure and properties of condensed phosphates VII. Hydraulic degradation of Pyro and Tri poly phosphates.J. Am. Chem. Soc. 77(2), 1955, 287- 291.

[10] J. W. Gilliam, and E. C. Sample, Hydrolysis of pyrophosphate in soils: pH and biological effects. Soil Sci. 106, $1968,352-357$.

[11] T. M.McBeath, R. J. Smernik, E. Lombi, and M. J. McLaughlin, Hydrolysis of pyrophosphate in a highly calcareous soil: A solid state phosphorus -31 NMR study. Soil Sci. Soc. Am. J. 70, 2006, 856- 862.

[12] R. P.Dick, and M. A. Tabatabai, Hydrolysis of polyphosphates in soils. Soil Sci. 142: $132-140$.

[13] C. D. Sutton, S. Larsen. 1964. Pyrophosphate as a source of phosphorus for plants. Soil Sci. 97, $1986,196-201$.

[14] J. W. Gilliam, Hydrolysis and uptake of pyrophosphate by plant roots. Soil Sci. Soc. Am. Proc. 34, 83 - 86.

[15] B.Raistrick, The influence of foreign ions on crystal growth from solution. Discuss. Faraday Soc. 5, $1949,234-236$.

[16] R. W.Marshal, G. H. Nancollas, The Kinetics of crystal growth of dicalcium phosphate dihydrate. J. Phys. Chem. 73, 1969, 38383844.

[17] E. M. El-Zahaby, and S. H. Chien. Effect of small amounts of pyrophosphate or orthophosphate sorption by calcium carbonate on calcareous soils.Soil Sci. Soc. Am. J. 46 1982, 38- 46.

[18] I. Hashimoto, J. D. Huges and O. D. Philen, Reaction of triammonium pyrophosphate with $\mathrm{SO}_{4}$ and minerals. Soil Sci. Soc. Am. Proc. 33, 1969, 401- 405 .

[19] L. O. Torres-Dorante, N. Classen, B. Steingrobe, and H. W. Olfs, Fertilizer use efficiency of different inorganic polyphosphate sources: effects on soil $\mathrm{P}$ availability and $\mathrm{P}$ acquisition during early growth of corn. J. of Plant Nurition and Soil Sci. 169(4), 2006, 509- 515 .

[20] G. E. Mattingly, and F. V. Woddowson, Residual value of superphosphate and rock phosphate on an acid soil I. Yields and phosphorus uptake in the field. J. Agric. Sci. 60, 1963, $399-408$.

[21] F.Zapata, and R. N. Roy, Use of phosphate rock for sustainable agriculture. FAO.Fertilizer and Plant Nutrition Bulletin.Rome. Italy, $13,2004$.

[22] O. P.Engelstad, AroonJugsujinda and S. K. DeDatta, Response by flooded rice to phosphate rock varying in citrate solubility. Soil Sci. Soc. Am. Proc. 38, 1974, $524-529$.

[23] A. L. Page, (ed.), Methods of soil analysis: Chemical and Microbiological Properties. (Am. Soc. Of Agron.Madison, 1982,) WI. USA.

[24] M. D. A.Bolland, R. N. Glencross, R. J. Gilkes and Vijay Kumar, Agronomic effectiveness of partially acidulated rock phosphate and fused calcium - magnesium phosphate compound with superphosphate. Fertilizer Research.32, 1992,169 - 183.

[25] N. M.Muhawish, and I. B. Razaq, Agronomic effectiveness of a new formula of phosphate fertilizer. I. Initial Agronomic Effectiveness. J. of Tikrit Univ. for Agric. Sci. 9, 2009, $617-625$.

[26] SPSS, Inc.SPSS statistics Base. 17.0 User's Guide. (SPSS Inc., Chicago. USA, 2008, Pp. 314- 319).

[27] J. K. Hassan, 1985. Effect of pyrophosphate on the availability of phosphate to corn plants (Zea mays L.) in some Iraqi soils. Master Thesis. College of Agric. Univ. of Baghdad, Baghdad, Iraq, 1985.

[28] F.Amer, and H. E. Mostafa, Effect of pyrophosphate or orthophosphate reaction in calcareous soils. Soil Sci. Soc. Am. J. 45, 1981, $842-847$.

[29] J. L.Havlin, J. D. Beaton, S. L. Tisdale, and W. L. Nelson, Soil fertility and fertilizers: an introduction to nutrient management. (Sixth edition.Prentice Hall.USA, 1999).

[30] N. A. A. Al- Saedy, Behavior and efficiency of ammonium phosphate feritilizers in calcareous soils. Master Thesis. College of Agric. Univ. of Baghdad,Baghdad, Iraq, 2000.

[31] N. M.Muhawish, Improving the effectiveness of PR through combining with organic materials and mixing with TSP in two calcareous soils. I. Direct effects. Al-Taqani J. 24, 2011, $8-18$.

[32] M. J. F. Dawood, Determination of phosphorus requirements for corn (Zea mays L.) using adsorption isotherm curves in a gypsiferous soil. Doctoral Thesis.College of Agric. Tikrit Univ, Tikrit, Iraq, 2016.

[33] K. H. Tan, Principles of soil chemistry. $3^{\text {rd }}$ edition.(Marcell and Dekker Inc. New York. Pp. 521, 1999).

[34] Wild, A. 1988. Russell's soil conditions and plant growth.(Longman Scientific and Technical. Essex. England. Pp. 991, 1988).

[35] H. Marschner, 1990. Mineral nutrition of higher plants.(Academic Press. London. Pp. 674, 1990). 
[36] R. K. Al-Kafaje, 2012. Effect of adding phosphate rock and organic matter on available phosphorus for wheat planted in gypsiferous soil, Master Thesis. College of Agric. Tikrit Univ, Tikrit, Iraq, 2012.

[37] K. H. Al-Migimia, Effect of tillage system, level and method of phosphate fertilizer application on growth and yield of wheat (TriticumaestivumL.) in a gypsiferous soil. Master Thesis. College of Agric. Tikrit Univ., Tikrit, Iraq, 2013.

[38] G. E. Santa- Maria, J. I. Moriconi, and S. Oliferuk, Internal efficiency of nutrient utilization: What it is and how to measure it during vegetative plant growth? J. of Exp. Botany.66, 2015, 3011- 3018.

[39] I. B.Razaq, A. H. Al-Hadithy, H. S. Al-Obaidi, A. F. Hassan, I. G. Rasheed, N. M. Muhawish, Mix of acidulated de-calcinated phosphate rock and elemental Sulphur as an effective phosphate fertilizer. Paper No. 1487.17 ${ }^{\text {th }}$ WCSS. 14- 21 Aug. 2002 Thailand, .

[40] L. L. Hammond, Agronomic measurement of phosphate rock effectiveness. In "Seminar on phosphate rock for direct application ".(Spec. Publ. IFDC. SI. Int. Fert. Dev. Cent. Muscle Shoals, Alabama, 1979). Figures and Tables

Table 1. Properties of the soils used in the pot experiment.

\begin{tabular}{|l|l|l|l|}
\hline Property & Unit & Heavy Texture soil & Medium Texture soil \\
\hline Clay & ${\mathrm{g} . \mathrm{kg}^{-1}}^{-1}$ & 413 & 240 \\
\hline Silt & ${\mathrm{g} . \mathrm{kg}^{-1}}^{-1}$ & 295 & 408 \\
\hline Sand & $\mathrm{g}_{\mathrm{kg}}$ & 292 & 352 \\
\hline Texture & - & Clay & Loam \\
\hline ECe & $\mathrm{dS} . \mathrm{m}^{-1}$ & 3.17 & 3.46 \\
\hline pHe & - & 8.02 & 7.91 \\
\hline Available P (Olsen P) & $\mathrm{mg} . \mathrm{kg} \mathrm{soil}^{-1}$ & 6.35 & 5.99 \\
\hline CEC & $\mathrm{cmol.kg} \mathrm{soil}$ & \\
\hline CaCO3 & g. kg soil & 20.6 \\
\hline
\end{tabular}

Table 2. Properties of the soils used in the field experiment.

\begin{tabular}{|c|c|c|}
\hline Property & Unit & Value \\
\hline Clay & g.kg $^{-1}$ & 360 \\
\hline Silt & g. $\mathrm{kg}^{-1}$ & 516 \\
\hline Sand & g. $\mathrm{kg}^{-1}$ & 124 \\
\hline Texture & - & Clay \\
\hline $\mathrm{EC}(1: 1)$ & dS.m ${ }^{-1}$ & 3.6 \\
\hline $\mathrm{pH}(1: 1)$ & - & 7.54 \\
\hline $\mathrm{OM}$ & ${\text { g. } \mathrm{kg}^{-1}}^{-1}$ & 4.1 \\
\hline $\mathrm{CaCO} 3$ & g.kg ${ }^{-1}$ & 305 \\
\hline Available P (Olsen P) & mg.kg soil ${ }^{-1}$ & 8.85 \\
\hline CEC & $\mathrm{cmol} \mathrm{Kg} \mathrm{soil}^{-1}$ & 23 \\
\hline
\end{tabular}

Table 3. Some chemical characteristics of phosphate rock used in the study.

\begin{tabular}{|l|l|l|l|l|}
\hline $\mathrm{P}_{2} \mathrm{O}_{5}$ & $\mathrm{P} \%$ & $\mathrm{CaO} \%$ & $\mathrm{Ca} \%$ & $\mathrm{CO}_{2} \%$ \\
\hline 30 & 13 & $56-58$ & 36 & 2.5 \\
\hline
\end{tabular}

Table 4. Effect of $P$ source and level, and soil texture on dry matter yield (g. $\operatorname{pot}^{-1}$ ) of corn (pot experiment)

\begin{tabular}{|c|c|c|c|c|c|}
\hline \multirow[t]{2}{*}{ Fertilizer } & \multirow{2}{*}{$\begin{array}{l}\text { P level } \\
\left(\mathrm{mg} \cdot \mathrm{kg}^{-1}\right)\end{array}$} & \multicolumn{2}{|l|}{ Soil } & \multirow[t]{2}{*}{ Mean P level } & \multirow[t]{2}{*}{ Mean fertilizer } \\
\hline & & Heavy Texture & Medium Texture & & \\
\hline \multirow{5}{*}{$\mathrm{K}_{4} \mathrm{P}_{2} \mathrm{O}_{7}$} & 0 & 26.50 & 23.50 & $25.00 \mathrm{C}$ & \multirow{5}{*}{$29.20 \mathrm{~A}$} \\
\hline & 10 & 30.85 & 24.41 & $27.63 \mathrm{BC}$ & \\
\hline & 20 & 33.77 & 24.62 & $29.20 \mathrm{BC}$ & \\
\hline & 50 & 35.05 & 28.68 & $31.87 \mathrm{AB}$ & \\
\hline & 100 & 36.06 & 28.56 & $32.31 \mathrm{~A}$ & \\
\hline Mean & & 32.45 & 25.95 & & \\
\hline \multirow{5}{*}{$\mathrm{KH}_{2} \mathrm{PO}_{4}$} & 0 & 26.50 & 23.50 & $25.00 \mathrm{C}$ & \multirow{5}{*}{$28.01 \mathrm{~A}$} \\
\hline & 10 & 27.00 & 24.71 & $25.86 \mathrm{BC}$ & \\
\hline & 20 & 27.71 & 27.00 & $27.36 \mathrm{BC}$ & \\
\hline & 50 & 28.97 & 29.28 & $29.13 \mathrm{AB}$ & \\
\hline & 100 & 34.49 & 30.93 & $32.71 \mathrm{~A}$ & \\
\hline Mean & & 28.93 & 27.08 & & \\
\hline Mean soil & & $30.70 \mathrm{~A}$ & $26.52 \mathrm{~B}$ & & \\
\hline
\end{tabular}

Values followed by different letters $(\mathrm{A}-\mathrm{C})$ in the same column are significantly different $(\mathrm{p}<0.05)$ 
Table 5. Effect of $\mathrm{P}$ source and level, and soil texture on $\mathrm{P}$ concentration ( $\mathrm{mg} \mathrm{P} \mathrm{kg}^{-1}$ plant tissue) in corn dry weight (pot experiment)

\begin{tabular}{|c|c|c|c|c|c|}
\hline \multirow[t]{2}{*}{ Fertilizer } & \multirow[t]{2}{*}{ P level $\left(\mathrm{mg} \cdot \mathrm{kg}^{-1}\right)$} & \multicolumn{2}{|l|}{ Soil } & \multirow[t]{2}{*}{ Mean P level } & \multirow[t]{2}{*}{ Mean fertilizer } \\
\hline & & Heavy Texture & Medium Texture & & \\
\hline \multirow{5}{*}{$\mathrm{K}_{4} \mathrm{P} 2 \mathrm{O}_{7}$} & 0 & 1000 & 1496 & $1248 \quad \mathrm{E}$ & \multirow{5}{*}{$1495 \mathrm{~B}$} \\
\hline & 10 & 1283 & 1635 & $1459 \mathrm{D}$ & \\
\hline & 20 & 1407 & 1672 & $1539 \mathrm{C}$ & \\
\hline & 50 & 1461 & 1727 & $1594 \mathrm{~B}$ & \\
\hline & 100 & 1513 & 1754 & $1634 \mathrm{~A}$ & \\
\hline Mean & & $1333 \mathrm{~B}$ & $1577 \mathrm{~B}$ & & \\
\hline \multirow{5}{*}{$\mathrm{KH}_{2} \mathrm{PO}_{4}$} & 0 & 1000 & 1496 & $1248 \mathrm{E}$ & \multirow{5}{*}{$1678 \mathrm{~A}$} \\
\hline & 10 & 1577 & 1752 & $1665 \mathrm{D}$ & \\
\hline & 20 & 1612 & 1880 & $1746 \mathrm{C}$ & \\
\hline & 50 & 1623 & 1981 & $1802 \mathrm{~B}$ & \\
\hline & 100 & 1647 & 2206 & $1927 \mathrm{~A}$ & \\
\hline Mean & & 1492 & 1863 & & \\
\hline Mean soil & & $1412 \mathrm{~B}$ & $1720 \mathrm{~A}$ & & \\
\hline
\end{tabular}

Values followed by different letters $(\mathrm{A}-\mathrm{C})$ in the same column are significantly different $(\mathrm{p}<0.05)$

Table 6 .Relationship between yield of dried tops and P uptake in the dried tops (Internal Efficiency, IE* of P use) for the pot experiment.

\begin{tabular}{|c|c|c|c|c|}
\hline \multirow{2}{*}{$\begin{array}{l}\text { P level } \\
\text { mg. } \mathrm{kg}^{-1} \text { soil }\end{array}$} & \multicolumn{2}{|c|}{ Heavy Texture } & \multicolumn{2}{|c|}{ Medium Texture } \\
\hline & $\mathrm{K}_{4} \mathrm{P}_{2} \mathrm{O}_{7}$ & $\mathrm{KH}_{2} \mathrm{PO}_{4}$ & $\mathrm{~K}_{4} \mathrm{P}_{2} \mathrm{O}_{7}$ & $\mathrm{KH}_{2} \mathrm{PO}_{4}$ \\
\hline 0 & 1000 & 1000 & 668 & 668 \\
\hline 10 & 779 & 634 & 612 & 570 \\
\hline 20 & 711 & 620 & 598 & 532 \\
\hline 50 & 684 & 616 & 579 & 505 \\
\hline 100 & 661 & 607 & 570 & 453 \\
\hline Mean & 767 & 695 & 605 & 546 \\
\hline
\end{tabular}

Yield of dried tops

$* \mathrm{I} . \mathrm{E}=$

P uptake

(Bolland et al., 1992)

Table 7. Effect of Fertilizer treatments on corn straw and corn ears weight $\left(\mathrm{kg}^{\mathrm{h}} \mathrm{ha}^{-1}\right)$ for field experiment

\begin{tabular}{|l|l|l|}
\hline Fertilizer & Corn straw $\left(\mathrm{kg} \cdot \mathrm{ha}^{-1}\right)$ & Corn ears $\left(\mathrm{kg}^{-1} \mathrm{ha}^{-1}\right)$ \\
\hline Control & $5500 \mathrm{D}$ & $5625 \mathrm{D}$ \\
\hline M5 & $10075 \mathrm{~B}$ & $8225 \mathrm{~A}$ \\
\hline Pyrophosphate & $10400 \mathrm{~A}$ & $8175 \mathrm{~A}$ \\
\hline TSP & $9875 \mathrm{~B}$ & $7350 \mathrm{~B}$ \\
\hline PR & $8000 \mathrm{C}$ & $6875 \mathrm{~B}$ \\
\hline MAP & $11700 \mathrm{~A}$ & $7375 \mathrm{~B}$ \\
\hline
\end{tabular}

Values followed by different letters $(\mathrm{A}-\mathrm{C})$ in the same column are significantly different $(\mathrm{p}<0.05)$

Table 8. Effect of Fertilizer treatments on grain yield and corn cobs weight $\left(\mathrm{kg} . ~ h a^{-1}\right)$ for field experiment

\begin{tabular}{|l|l|l|}
\hline Fertilizer & Grain yield $\left(\mathrm{kg}^{-h^{-1}}\right)$ & Corn cobs $\left(\mathrm{kg} \cdot \mathrm{ha}^{-1}\right)$ \\
\hline Control & $4721 \mathrm{D}$ & $1294 \mathrm{C}$ \\
\hline M5 & $6323 \mathrm{~A}$ & $1892 \mathrm{~A}$ \\
\hline Pyrophosphate & $6266 \mathrm{~A}$ & $1880 \mathrm{~A}$ \\
\hline TSP & $5664 \mathrm{~B}$ & $1691 \mathrm{~B}$ \\
\hline PR & $5260 \mathrm{C}$ & $1581 \mathrm{~B}$ \\
\hline MAP & $6107 \mathrm{~A}$ & $1696 \mathrm{~B}$ \\
\hline
\end{tabular}

Values followed by different letters $(\mathrm{A}-\mathrm{C})$ in the same column are significantly different $(\mathrm{p}<0.05)$

Table 9. Relative Agronomic Effectiveness of various phosphates depending on corn grain yield.

\begin{tabular}{|l|l|l|}
\hline P source & Grain Yield $\left(\mathrm{kg} \mathrm{ha}^{-1}\right)$ & RAE \\
\hline TSP & 5664 & 100 \\
\hline M5 & 6323 & 170 \\
\hline Pyrophosphate & 6266 & 164 \\
\hline PR & 5260 & 57 \\
\hline MAP & 6107 & 147 \\
\hline
\end{tabular}

$R A E=\frac{Y F-Y c}{Y R-Y c} * 100($ Engelstad et al., 1974) 